\title{
IV. Mlutitizen.
}

\section{Entgegnung.}

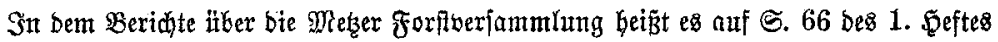
1894 biejer Beitjdxift: „Dberförfter $\Re$ a u afabentiden Erörterung über bie "wanbelbare Sinft" Der Forfteintidung unb verurteilte

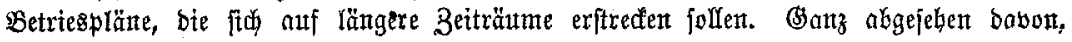

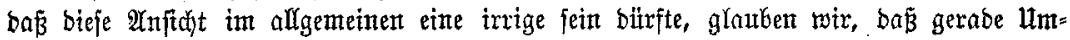

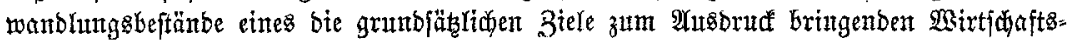

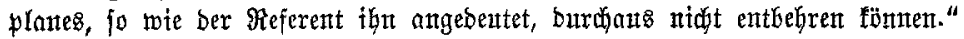

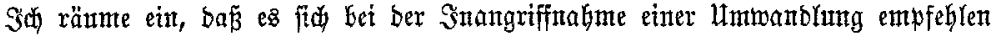

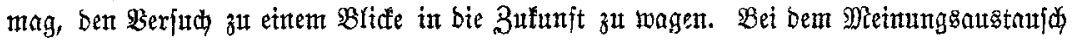

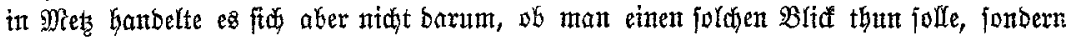

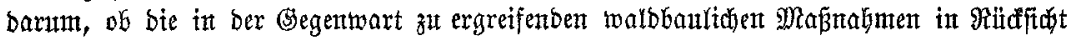

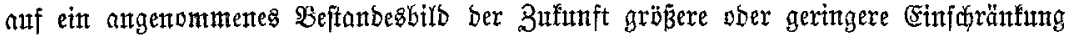

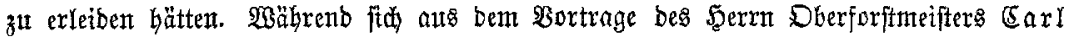

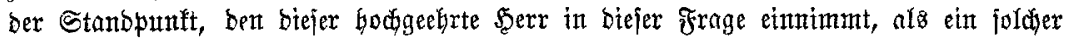

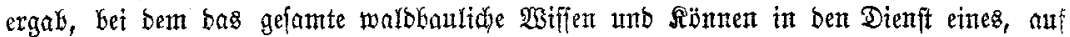

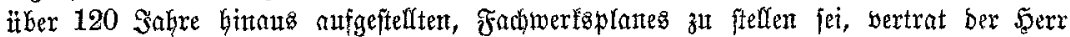

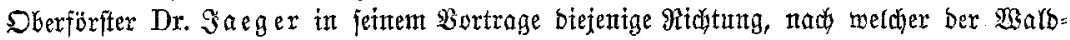
bau bie Şerritt złt fein, bie Forjteinriduttntg aber etne untergeorbnetere Rolle zut fpielen

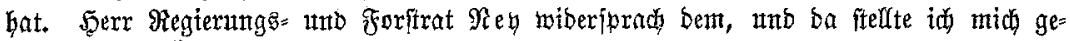

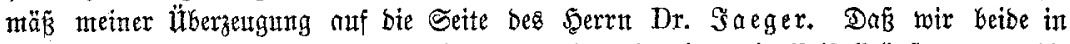

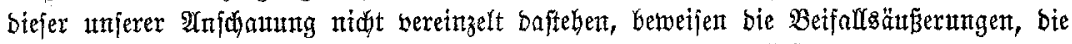

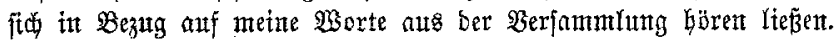

(5s giebt in Deutidfnno bereits zwet Staaten, in benen jeber Forfteintiditungs:

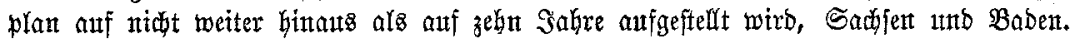

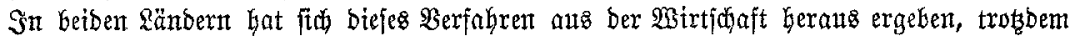

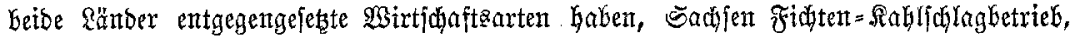

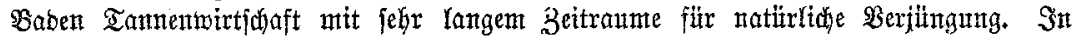

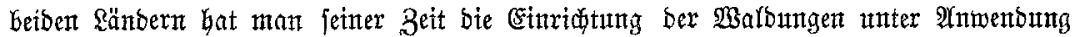

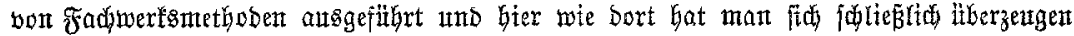

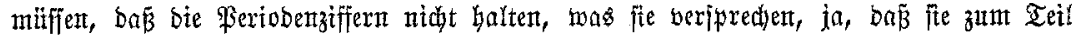

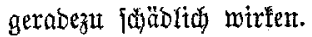

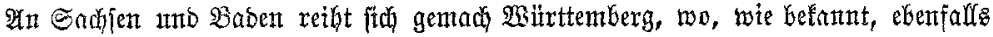

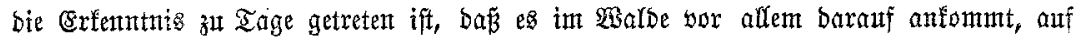

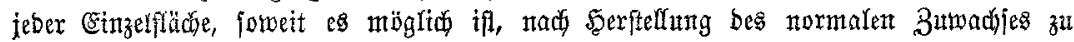

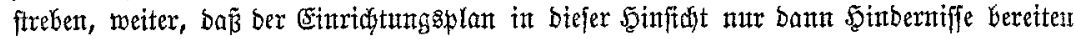

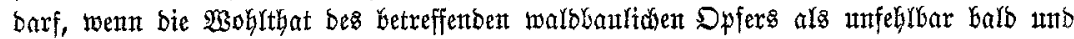

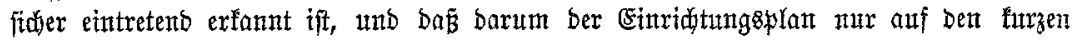
Bettraum binats aufgeffellt werben jollte.

Sul $\mathfrak{l}_{z}$ in Sberelfaffe, Den 13. Febran 1894. 